\title{
Archive Footage and the Image of Historical Documentary
}

\author{
Mohd. Nor Shahizan Ali ${ }^{1}$, Ali Salman ${ }^{1}$, Novel Lyndon ${ }^{1}$, Mat Pauzi Abd. Rahman ${ }^{1} \&$ Yuszaidy Mohd. Yusoff ${ }^{1}$ \\ ${ }^{1}$ University Kebangsaan Malaysia, Malaysia \\ Correspondence: Mohd. Nor Shahizan Ali, University Kebangsaan Malaysia, Malaysia. E-mail: \\ shahizan@ukm.my
}

Received: February 16, 2013 Accepted: March 29, 2013 Online Published: April 25, 2013

doi:10.5539/ass.v9n8p116

URL: http://dx.doi.org/10.5539/ass.v9n8p116

\begin{abstract}
This research aims to unveil the royal agenda issues on the documentary 'Jungle Green Khaki Brown: Malaya's fight against terrorism'. 'Jungle Green Khaki Brown: Malaya's fight against terrorism' is a documentary that members devote to his struggle againstcommunist terrorists safety. Every aspect of the documentary is to be visualized representation of the struggle against bandit. A series rather than social factors, technological and cultural influence beyond the eroding attitude formation are still obscure Malaysian nation with a history of their own country. 'Jungle Green Khaki Brown: Malaya's fight against terrorism' has become a silent byproduct material injected historical value and value in the eyes of the Bangsa Malaysia (Malaysian Nation). This documentary has been a witness to the history that applies to every Bangsa Malaysia (Malaysian nation). The problem is there message this kingdom can achieve set goals? Overview over the audience documentary has run to get their views on the visual elements shown owing to documentary, is there they see it as something that actually describes the situation or just a symbolism? The model form in visual communication backing up two possibilities: the audience will be able to understand any visual elements that display as it is constituted by language (Barthes), or visual communication, such as sign language and has put imagery, and create something of meaning (Kress and Van Leeuwen), to make room for the audience to 'read' thoroughly about what to say, like what otherwise is a documentary that free offerings actually. This study rejects both those views. The image may communicate without language, but there is a very striking distinction between the images that make up the easy system and language imagery that form a complex system. The semiotic system imagery is easy to represent the real existent (Halliday) and every experience we went through. The existence of index alongside the linguistic discourse allows the audience to understand every visual offering by linking each index with the actual state of the world. The implication can add further unique offerings and appeal over the documentary.
\end{abstract}

Keywords: archive footage, visual image, historical documentary, Bangsa Malaysia (Malaysian nation), visual communication, symbolism

\section{Introduction}

Showing documentaries through local television channels has become a trend nowadays. 'Jungle Green Khaki Brown: Malaya's fight against terrorism' for example is a documentary that revolves around the struggle of the security forces for 12 years (1948-1960) in the fight against communism in Malaya. Security forces in green uniform, while the terrorists with 'khaki brown'. A documentary featuring the art of war and unrest as well as principles and human rights and love of the nation and country by the fighters has been filmed by adding visual application archive (archive footage). Certainly this is not a documentary narrative plot with entirely new visuals, because the historical new approach of archives documentary need to strengthen the nation's history in the story.

Visually portrayed in 'Jungle Green Khaki Brown: Malaya's fight against terrorism which in turn is how representation of the land as a source of Malaya to the development of the world economy. Then this is followed by the security forces in the 'green' forest against the communists 'khaki brown', followed by the statement 'if they (security forces) are dead or hold the communists'. Visual is screened with black and white background to reflect the struggles of resistant historiography factors on communist terrorists. Visual is also taken from the film archives to strengthen documentary historiography storyline. The use of visual archive (archive footage) in the new approach of historical documentary has germinated in the broadcast industry nowadays. The use of this visual archive rather than narrative plot strengthens the documentary and also at a lower cost.

Machin (2004) stated that the use of photography and visual images in the mass media has led to a global image. 
He stressed that the use of the photographic image as symbolic prefigures happens in every event. Machin (2004) suggested that the use of more pictures lead to connotation meaning versus denotation meaning. This visual archive is available from banks to assist in producing iconic image to each event that has occurred in the past to look back at history.

This statement is supported by Bennett (2005) who states that currently reporting patterns had changed from being solely focused only on the current reality, pattern editing, report technique (style), which is more concerned with marketing purposes. This makes the pattern of the event reports to be more concerned with understanding the audience on the purpose elements of a story and make the report as a complete presentation in a clear package.

The documentary 'Jungle Green Khaki Brown: Malaya's fight against terrorism' analyzed in the article is more geared to the use of archives in describing the visual narrative, and give an insight to the audience, particularly the younger generation to understand and appreciate the history of the struggle of the figures in the fight for independence. Not least is, the application of values the importance of unity among the people of Malaysia and to be expressed through the visual use. The use of visuals seen on the visual aspects of the symbolic meanings and connotations.

The objective of this research is based on the process of understanding the audience on the documentary 'Jungle Green Khaki Brown: Malaya's fight against terrorism' and it will take into consideration that; Audiences are trained to understand every issue with a broader view and open (Hartley, 1982). They scan every event with the memory. They were exposed to accept all this as 'reality'; Editing a documentary is different from editing the film, which is visually depicted each must be proved by the fact of a narrative (rhetoric) particularly the historical evidence; There are some differences between the images that make up a simple symbol system (Halliday 1985), with language that forms a complex symbol systems. Halliday stated a simple representation of a semiotic system more similar to the phenomenon experienced by everyday experience. So, we cannot assume that the audience will see every visual element in the form of words of the symbolic connotations. They will look at each of these elements as appearance.

Generally, it can be illustrated that visual documentary presentation has 'strength' to describe every real situation based on the facts, and in some cases it can get rid of denotation meaning embodied in visual presentation.

\section{Data}

The data used in this analysis is a documentary, titled 'Jungle Green Khaki Brown: Malaya's fight against terrorism' which was aired on TV3 from 12 September 2011 to 11 October 2011, a total of eight episodes. The duration of this documentary is 2 hours 15 minutes.

\section{Method of the Study}

A survey was conducted on 100 respondents who watched the documentary 'Jungle Green Khaki Brown: Malaya's fight against terrorism', which was (re)premiered at the Tun Seri Lanang Library (PTSL), Universiti Kebangsaan Malaysia (UKM). Respondents then answered the survey questions that were handed to them after watching the documentary. Descriptive analysis on some interesting aspects related to the use of visual elements and acceptance towards the government's agenda to history and construction of Bangsa Malaysia (Malaysian Nation) in the form of unity based on the documentary.

The production of documentary 'Jungle Green Khaki Brown: Malaya's fight against terrorism' is based on the use of visual archives (archive footage) as the basis for the plot of this documentary. This documentary is based on the delivery method 'telling stories'. Documentary productions' are not based on historical narrative plot in 'straight' (straight forward). The use of visual archive (archive footage) has become as 'wallpaper' to illustrate every word to be presented with two methods of narrative approach, which is to describe the visual effects, and to combine voice and visual background. Next, the storyline was infused with interviews with former combatants in the security forces and leaders who are involved directly and indirectly in the struggle against terrorists and fight for independence.

\subsection{Why TV3?}

System Television Malaysia Berhad (TV3) is a television station that has the most number of viewers of TV terrestrial stations (AC Nielsen 2012). The cooperation of the Ministry of Culture, Arts and Heritage of Malaysia (folder), the National Film Commission (FINAS), Telekom Malaysia (TM), and Affin Bank reinforces the government's agenda in the values of this nation struggle and unity among the various races in Malaysia. 


\subsection{Government Agenda}

The introduction of digital technology in the broadcast industry has caused the use of little staff in producing any program. Furthermore, the direct use of technology to manipulate every visual element that can produce a perfect production (Ursell, 2001). So, this opportunity is used by the government to issue a documentary 'Jungle Green Khaki Brown: Malaya's fight against terrorism' that loaded with visual archive (archive footage) to create awareness on the audience about the struggle against the communist security forces towards independence. Most of the production of broadcasting today is the result of a combination of the latest visual and visual material archive (archive footage), then the overall result of this production are accepted by the community, and supported by advertisers (Machin \& Niblock, 2006).

On the realization that the Prime Minister Dato' Seri Najib Tun Abdul Razak explained on the launch of this documentary on TV3 on 28 July 2011 that the fact of formal education does not just end after the end of school or institution of higher learning. New knowledge can be grasped with the use of technology, and will be carried on an ongoing basis. The culture of lifelong learning and a passion to gain knowledge to be cultivated in society (NajibTun Abdul Razak, 2011). The use of documentary as a tool in disseminating information to the community is what prompted the government to put the love for the country and unity agenda to generation in this country by airing the documentary 'Jungle Green Khaki Brown: Malaya's fight against terrorism'.

Ekström (2000) support the existence of technology makes production easier and 'interesting'. He put the development of this technology as an enabler to create a production that trace viewer. This resulted in changes in the production moved from mere visual presentation on the use of graphics, maps, effects, tables, and restructuring. Visual material archive (archive footage) used in this study is part of the process of applying these materials (visual form), in the production of elements that can trace viewers.

The other thing to consider is the visual archive (archive footage) and text used in this documentary to form a discourse (Fairclough, 2001). That is, discourse as a shared knowledge about the world and everything that happens in it. For example the word 'terrorism' here means that it was agreed that the group is 'fanatic' and the enemy of the 'independence'. Not all discourses give meaning similar acceptance to every individual, especially for individuals who do not have experience of the visual.

Machin (2004) states that the amber archive photographs used in a narrative have a 'broad meaning potential'. According to him, archival photographs have a very high value meaning when it succeeded in forming potential connotative meaning. Based on this notion, the use of visual archives (archive footage) in the documentary 'Jungle Green Khaki Brown: Malaya's fight against terrorism' aims to create an index in a perfect means of NEW APPROACHED OF documentary history.

Discourse of race and racial solidarity Malaysia now not only the government's agenda, but the agenda also reflected to the documentaries producers and documentary proceeds can be seen shaping society's thought about how the Bangsa Malaysia (Malaysian Nation)should exist. Unity to be expressed by the issuer in remembrance of the society about the plight gained independence struggle.

A study conducted by Ekström in 2000 also showed the documentary works not only for entertainment, but it is used to communicate values to their audience. These values are multi-ethnic, unity, harmony and life style of the people and also serve as a tool for social development.

Documentary 'Jungle Green Khaki Brown: Malaya's fight against terrorism' is also seen as a government propaganda tool. According to Severin and Tankard (2001), one example Bandwagon (propaganda tool) is entertainment. Bandwagon aims to make the audience accept an idea accepted by the members in the group. Documentary 'Jungle Green Khaki Brown: Malaya's fight against terrorism' have agendas and race portrayals Malaysia and fosters racial unity and the spirit of love for the country in this documentary that could allow the establishment of the agenda.

In the words of Smith (1991) cited by Ekström (2000) in the journal article, in view of the media in forming a unity within a nation, we look at how the process of nation building and how the media took the build (construct) a 'national culture' and 'national community'. Nation-state must have a shared culture and civic ideology, a set of understandings and aspirations, sentiments and ideas that unite people together in the country. History and chronology towards independence should be carefully studied and known by all members of society.

Visual construction of the 'Jungle Green Khaki Brown: Malaya's fight against terrorism' is based on the approach in the understanding of the people of Malaysia produces about the labor-smarting and history-independence elements. The importance of this context is based on statements from Briggs and Burke saying that “...the immediate intentions, strategies and tactics of communicators need at every point in the story 
to be related to the context in which they are operating along which the messages they are communicating." (2005: 151).

This understanding is expressed through documentary 'Jungle Green Khaki Brown: Malaya's fight against terrorism which has been consolidated by using a' new 'in the delivery the new approached of documentary history. Sociologist Pierre Bourdieu, stressing that "journalists should be exposed to professional broadcasting to the production of the 'extraordinary' on every routine needs outside the norm" (Bourdieu, 1996: 20). In the field of documentary production, he describes the importance of producing the form 'intuitive understanding'. Producers need to produce a documentary that focuses on the style of thinking and intuitive 'theme', which will highlight the issues and plot narrative to the audience with the assumptions and thinking beyond the boundaries of normal.

Consent must be obtained in understanding the 'intuitive' meaning. If producers expect the audience to understand the patterns of delivery of 'new documentary', the question is whether producers of documentary 'Jungle Green Khaki Brown: Malaya's fight against terrorism' laid the foundation that all people today understand chronological history of Malaysia's independence? There are two large generation post-independence generation, aged between 18-30 years and the post-independence generation aged 30 years and above, the target group of this documentary. The question is whether the two groups are to understand every inch of the chronology of the history of independence? The changes also affect their perception and their sense of patriotism.

Efforts to improve the understanding of 'intuitive' in the audience is strengthened by step producer of documentary 'Jungle Green Khaki Brown: Malaya's fight against terrorism' that interviewing personalities involved with emergency events (1948-1960). The interviews are intended to give a clear picture to the audience about the events that took place at that time and followed by its own narrative of each individual experience. Visual interviews well grasped and effectively in the documentary 'Jungle Green Khaki Brown: Malaya's fight against terrorism' to give visual impact and support the archive (archive footage) in providing a better understanding to the audience of this documentary.

\subsection{Visual Elements in 'Jungle Green Khaki Brown: Malaya's Fight against Terrorism' Montage}

Montage is a combination of visual range in a scene at a time. This combination consists of a separate dialog or in a frame (frame) separately. All frames (frame) will appear in the scene in rotation. Viewers can see this without feeling confused. Nichols (1991) suggests that in the documentary, 'montage' does not reflect the whole story, but describes a comprehensive view of the real world. This documentary uses visual archive (archive footage) to reflect a comprehensive view of the real world.

In the view of the audience, the possibility 'montage' does not reflect the real world view. Do they see the 'montage' is a truth of the narrative or symbolic elements? The truth is, 'montage' reflects the actual element, even though the order was planned. In view of Kress and Leeuwen (1996), they stated that a visual representation, such as non-realistic colors, which is displayed to the audience is less truth (low modality), rather than what should be displayed. However, not necessarily understanding the audience expressed only on the truth of any of the visual display, but can also depend on how the visual is construct (Machin 2004).

\subsection{Plot - Visual Archive as Truth Index}

Enactments of the plot for documentary ‘Jungle Green Khaki Brown: Malaya's fight against terrorism' use visual archive (archive footage) to reflect the actual situation which occurred in the emergency era (1948-1960). So, the truth of the documentary is shown in the message 'visual reality' used in describing the real situation. Viewers are able to appreciate and understand the natural content (new approached of) reflected through the visual. Barthes (1977), states that an image can be interpreted with different meanings, assisted by the wording of the texts that represent the image. Compilation of images can carry a variety of potential meanings of 'founded language'.

This opinion, however, was rejected by Kress and Leeuwen (1996), based on two approaches. Firstly, they believe that all of the text is 'multimodal' that combines linguistic, visual, and any presentation mode. So, language and images can be combined simultaneously in producing meanings. Secondly, each text and visual (image) is based on a foundation, which aims to strip, so it should be linked to culture, and experience. Thus, each has a specific structure, and self-reliance. Machin (2004) also commented on the 'visual verb' which is something that can be visually brought together (multimodality) with language without words to create meaning.

Productionsof the documentary 'Jungle Green Khaki Brown: Malaya's fight against terrorism' is based on image interpretation which holds to the principle that visual image is different from the linguistic symbols. This 
approach is taken into account based on the statement of Halliday (1985) which states that a complex system of symbolism, such as language, apart from the meaning of the symbol grammar usage. However, for a simple representation of the system, meaning is built from real world phenomena (reality). Experience and observation to make the audience understand each visual meaning based on the actual phenomena. The narrative in documentary image 'Jungle Green Khaki Brown: Malaya's fight against terrorism' does not appear only with the restructuring of symbolism as it appears on the complex system of symbolism.

This understanding can be said to be 'creating meanings for the image' is different to 'creating words to reality'. This understanding coupled with documentary producers 'Jungle Green Khaki Brown: Malaya's fight against terrorism' which incorporates interviews with former leaders involved in the efforts of the communist resistance. So, these interviews will help in allowing viewers to see every visual phenomenon associated with the actual. The use of visual archive (archive footage) has lead to a feeling in the audience to understand the documentary 'Jungle Green Khaki Brown: Malaya's fight against terrorism' as a matter of history.

\section{Results of the Study}

Based on the results obtained from a survey conducted on 100 respondents find out that, there are some interesting aspects related to visual elements used and the acceptance towards the government's agenda to the historical construction of race Malaysia and national unity in this documentary.

The documentary was not popular among the respondents and this is evidenced by 51 percent strongly agree with the statement of not knowing screening of this documentary on TV3. In fact, $92 \%$ of those watching it for the first time on the day of the study performed. Meanwhile, $98 \%$ of respondents agree that they understand the way the narrative (plot) of this documentary. There are only $7 \%$ of respondents agreeing that this documentary presenting about racial unity and the construction of Bangsa Malaysia (Malaysian Nation).

Agenda-determination theory assumes that the media can influence public opinion in the event, it gives more attention to some of the issues and reduces attention to other issues to think about by the public (Severin \& Tankard 2001). This point should not be used in documentary production 'Jungle Green Khaki Brown: Malaya's fight against terrorism', because respondents see more of this documentary narrative history of the struggle in gaining independence. The question of the construction of race and racial unity Malaysia in the documentary 'Jungle Green Khaki Brown: Malaya's fight against terrorism', cannot be traced by a large number of respondents.

The next question is seen, there is a relationship between the use of visual archives (archive footage) in this documentary with the expression of the characteristics Bangsa Malaysia (Malaysian Nation) and solidarity between people, results found that they cannot be accepted. Results show that $93 \%$ of respondents did not agree that the use of visual archives (archive footage) in reality there is expression of the characteristics of race and unity Malaysia.

Based on these responses, it appears true the view of Halliday (1985) which states that a simple image a picture of the reality and shows what human and life form that can be passed. Documentary 'Jungle Green Khaki Brown: Malaya's fight against terrorism' can be seen from a visual presentation which means connotation with a picture of the reality of the documentary at the time of the emergency, but the government's attempt to apply the form of the Malaysian nation and solidarity between people fail to understand the respondents.

Picture of the reality for the construction of race and racial unity Malaysia to be expressed by the government in the documentary led in turn to the question of whether the picture can be realized in the reality of today's Malaysia. Although the documentary 'Jungle Green Khaki Brown: Malaya's fight against terrorism' only managed to convince his audience that the battle fought the terrorists in order to achieve independence, but the agenda in fostering patriotism in building construction of race and racial unity Malaysia failed in achieving its goals. This is based on test respondents stated there is no relationship between the documentary 'Jungle Green Khaki Brown: Malaya's fight against terrorism' as a government tool to display the characteristics of the construction of race and racial unity Malaysia through the screening of this documentary.

In conjunction, it also evident that respondents strongly disagree and disagree with the statement that they felt understood the construction Bangsa Malaysia (Malaysian Nation) and solidarity between people when watching the documentary 'Jungle Green Khaki Brown: Malaya's fight against terrorism' with percentages 37 and 45 percent. Amount of both is 82 percent, which is more than half the respondent. This led to the finding that the documentary 'Jungle Green Khaki Brown: Malaya's fight against terrorism' for the respondent only displays on the history of resistance to the security forces on terrorism for independence.

The next question is on the relationship among the agenda of TV3, Ministry of Culture, Arts and Heritage of 
Malaysia (folder), the National Film Commission (FINAS), Telekom Malaysia (TM), and Affin Bank in realizing the government's intention to increase awareness about the importance of appreciating the independence. A total of $85 \%$ supported the move played by each of these bodies.

In relation to the expression of the characteristics of history, nurturing Malaysian race, and national unity in the documentary 'Jungle Green Khaki Brown: Malaya's fight against terrorism', it can be agreed that these agencies are bound by government policy, as they are trying to realize the government's creation of a united Bangsa Malaysia (Malaysian Nation) and love which is the first hurdle contained in the nine challenges to be faced, cooperate together, and resolve by the community and Malaysia as a whole (Hood Salleh et. al. 1991).

\section{Conclusion}

Based on the studies that have been conducted on the documentary 'Jungle Green Khaki Brown: Malaya's fight against terrorism', there are some questions answered: that the use of visual archives (archive footage) for a historical documentary leads to easy understanding by the respondents, because the respondents could understand a simple image, and felt that the incident really happened. The use of archived visual (archive footage) is a more intuitive 'trace' interspersed by interviews with people who have been involved in the realization of this documentary.

Denotative aspects from the production of this documentary failed to influence the respondents, because the respondents were only looking at the documentary with a connotative view. The agenda is, each visual image should be explained to respondents in advance. This explanation can provide some influence on the respondent to see an image that will lead to the next on a second layer of meaning. This study was conducted on university students as post-independence groups (18-30 years), and they did not experience what occurred at the time of emergency. So it's likely to be a hindrance to them to look to the image, which has the implied meaning / second layer (denotative).

This question has been described by Halliday (1985), i.e. 'Image can communicate without language, but there are very significant differences between the images that make up the system easy and language signified that form a complex signified system. Signified in simple semiotic system represents a real existence (Halliday, 1985) and approach that we went through. Existence of linguistic index in conjunction with a discourse allows the audience to understand every visual presentation by associating each index with real world conditions. The implication is to increase the natural performance to be a magnet for documentary.

There is likelihood of the respondents not able to relate the incident of the past compared with the 70s generation (post-independence aged 30 years and above) who are able to associate with past experience. Malaysian nation-building and national unity among the races should be depicted by other things, such as 'symbol'. Screening for unity during the Malayan Union, looked at as a 'multi-racial human relation', nowadays maybe this needs to be viewed from different angles because today's generation are different, hence there must exist a symbol, such as 'flag' or 'rule of the country'. This understanding can be said to be 'creating meanings for the image' which is different from 'creating words to reality' (Halliday 1985).

So, the entire narrative of the documentary 'Jungle Green Khaki Brown: Malaya's fight against terrorism' is understood by the respondents merely as 'a struggle against terrorist by security personnel in order to obtain independence' but not able to appreciate the whole concept of nation building and national cohesion. The image of visual archive history in the form of archive footage planned to reveal a racial agenda, the so called Bangsa Malaysia (Malaysian Nation) is getting lost in unity!

\section{References}

Barthes, R. (1977). Image - Music - Text. London: Fontana.

Bennett, W. L. (2005). News: The Politics of Illusion. London: Longman.

Bordwell, D. (1985). Narration in the Fiction Film. London: Methuen.

Bourdieu, P. (1996). On Television and Journalism. London: Pluto Press.

Briggs, A., \& Burke, P. (2005). A Social History of the Media. Cambridge: Polity Press.

Ekström, M. (2000). Information, Storytelling and Attractions: TV Journalism in Three Modes of Communication. Media, Culture \& Society, 22, 465-492. http://dx.doi.org/10.1177/016344300022004006

Fairclough, N. (2001). Language and Power: Language in Social Life. London: Longman.

Fowler, R. (1991). Language in the News: Discourse and Ideology in the Press. London: Routledge.

Halliday, M. A. K. (1985). An introduction to Functional Grammar. London: Edward Arnold. 
Hartley, J. (1982). Understanding News. London: Routledge.

INTAN. (2011). Pembangunan modal insan: Koleksi ucapan Dato'Seri Najib Tun Abdul Razak. Petaling Jaya: InstitutTadbiranAwam Negara.

Keyton, J. (2006). Communication Research (2nd ed.). New York. McGraw-Hill.

Kress, G., \& Van Leeuwen, T. (1996). Reading Images - The Grammar of Visual Design. London: Routledge.

Kress, G., \& Van Leeuwen, T. (2002). Colour as a Semiotic Mode: Notes for a Grammar of Colour. Visual Communication, 1(3), 343-368. http://dx.doi.org/10.1177/147035720200100306

Machin, D. (2004). Building the World's Visual Language: The Increasing Global Importance of Image Banks in Corporate Media. Visual Communication, 3, 316-336.

Machin, D., \& Niblock, S. (2006). News Production: Theory and Practice. London: Routledge. http://dx.doi.org/10.1177/1470357204045785

Nichols, B. (1991). Representing Reality. Bloomington: Indiana University Press.

Nielsen, A. C. (2011). Market Review.

Salleh, H., Said, K. M., \& Mois, A. H. A. (1991). Wawasan 2020 dan Pembinaan Bangsa Malaysia. Bangi: Universiti Kebangsaan Malaysia.

Severin, W. J., \& Tankard, J. W. J. (2001). Communication Theories: Origins, Methods, and Uses in the Mass Media. Amerika Syarikat. Addison Wesley Longman, Inc.

Ursell, G. (2001). Dumbing Down or Aping Up? New Technologies, New Media, New Journalism. Visual Communication, 3, 328-336. 